\title{
AGRICULTURE MODELLING IN THE EUROPEAN UNION
}

\author{
Aleksandra Rizojeva-Silava, $\mathrm{MSc}^{1}$; Sandija Zeverte-Rivza, $\mathrm{PhD}^{2}$; \\ Irina Pilvere, $\mathrm{PhD}^{3}$
}

Faculty of Economics and Social Development, Latvia University of Agriculture

\begin{abstract}
Agriculture is an important sector of the national economy. Modelling in agriculture is extensively used to evaluate and simulate the development of this industry. There are two main purposes for the development of agricultural models: to develop a scientific understanding of a particular system and obtain information in order to justify agricultural policy decisions and predict their implications. The purpose of this study is to analyse the models used in agriculture in the European Union (EU). To reach these purposes, the following research tasks were set: (1) to analyse the theoretical aspects of simulation modelling; (2) to explore the key agricultural simulation models employed in the EU. The research found that simulation modelling is often used in agriculture by policy makers. There are eight key models of different complexity which are being used to predict the development of the agricultural sector in the EU.
\end{abstract}

Keywords: agriculture, simulation, models, system

JEL codes: C50, Q10

\section{INTRODUCTION}

Agriculture is a significant sector of the national economy, which is aimed at the acquisition of food products of plant and animal origin and/or the extraction of other raw materials for industrial purposes. Since 1962 the agricultural sector in the EU has been governed by a Common Agricultural Policy (CAP). There are two main purposes for the development of agricultural models. The first general aim is to develop a scientific understanding of a particular system. This allows for the assessment of the elements of the agricultural sector system or the interconnectedness between individual elements and the whole system. The second general aim is to obtain information in order to justify agricultural policy decisions and predict their implications. The key advantage of these models is the presentation of reliable information (Zeverte-Rivza, Nipers and Pilvere, 2017).

The purpose of the present research is to analyse the models used in agriculture. To reach the purpose, the following research tasks were set: (1) to analyse the theoretical aspects of simulation modelling; (2) to explore the key agricultural simulation models employed in the EU.

${ }^{1}$ Corresponding author: Liela 2, LV-3001 Jelgava, Latvia, aleksandra.rizojeva@gmail.com, +371 26703531

${ }^{2}$ Corresponding author: Liela 2, LV-3001 Jelgava, Latvia, sandija.rivza@llu.lv, +371 26387278

${ }^{3}$ Corresponding author: Liela 2, LV-3001 Jelgava, Latvia, irina.pilvere@llu.lv, +371 29217851 


\section{THEORETICAL BACKGROUND}

Simulations are very important because they are able to prevent catastrophic failures in the system. A simulation model is developed to study the functioning of a system (Sharma, 2015).

The system dynamics theory is based on testing associations between a system's behaviour and system structure. The term system is defined as a collection of components that frequently interact over time to form a unified whole. The term dynamics pertains to change over time. System dynamics provides a common communication tool connecting many academic disciplines (Martin, 1997). In agricultural economics, simulation models that forecast the functioning of separate decision-makers are usually based on mathematical programming methods (Berger, 2001). System dynamic modelling is widely used in agricultural modelling.

The type of modelling approach chosen depends on the purpose under analysis and the question of interest. For example, partial and general equilibrium models are primarily applied to evaluate trade policies or the market impact of coupled domestic cost support policies. Regarding individual types of farms, these models are used to define 'representative farms' and to represent the behaviour and characteristics of a group of farms (Happe, Balmann and Kellermann, 2004).

The general equilibrium theory represents the economy as a selection of economic agents making delivery and demand decisions over goods, labour types and assets, in order to further interests (Bryant, 2010). These kinds of models are used extensively in policy analysis. Such models have been developed for countries and are suitable in many settings, ranging from the world to disaggregated regions within a country (Lofgren, Harris and Robinson 2002).

Partial equilibrium models represent particular sub-sectors or groups of agricultural sectors, and are applied in the detailed analysis of both sides of an equation, namely delivery and demand or policy impact, etc. Partial equilibrium models are often based on regression analysis and are frequently used to model the agricultural sector (Kotevska, Dimitrievski and Erjavec, 2013).

The basic units of agent-based models are 'agents' Agents can be anything from cells to biological entities, from individuals to social groups and can also be composed of other agents. (Richiardi, 2012). Agentbased models of agricultural structures enable the conduct of computer experiments that allow a better understanding of agricultural systems, structural changes and endogenous adjustment responses that arise in response to changes in politics (Happe, Balmann and Kellerman, 2004).

Hybrid models are created by combining advantages inherent in system dynamic models and agentbased models. Such models are usually generated from individual modules that include data obtained from agent-based simulations and exogenous data on the specific system (Zeverte-Rivza, 2017).

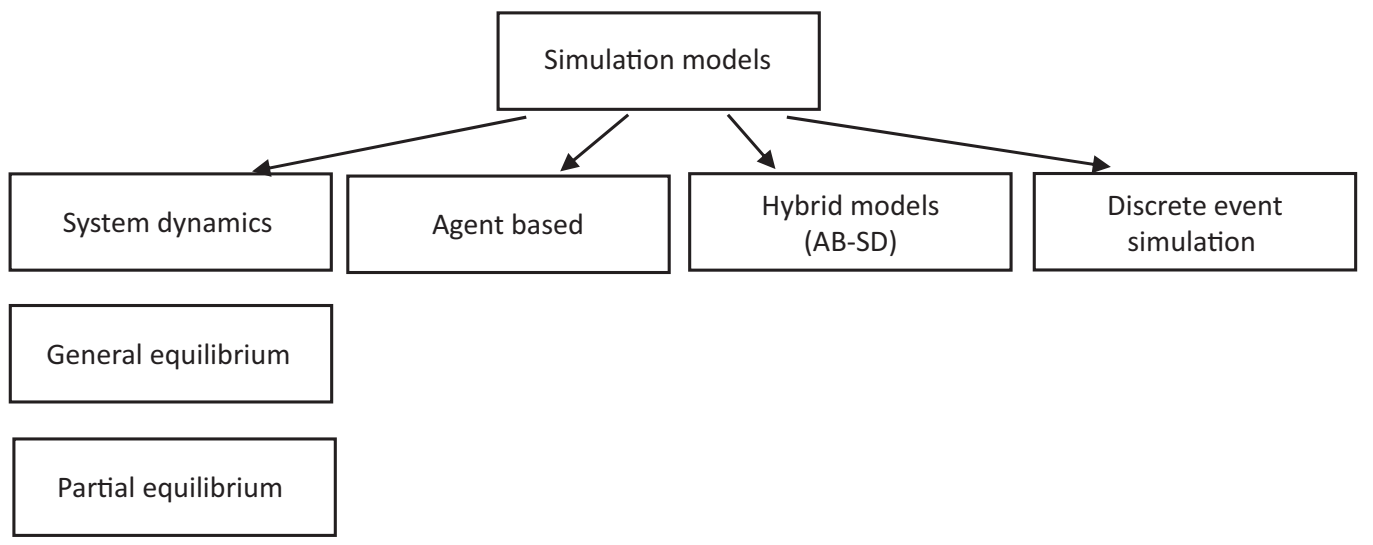

Figure 1. Classification of simulation models Source: authors' construction based on Zeverte-Rivza, Nipers and Pilvere (2017). 


\section{MATERIALS AND METHODS}

To execute the research tasks, the authors of this study used scientific literature review and methods of analysis and synthesis, namely the logical and constructive methods as well as induction and deduction analysis methods.

\section{RESULTS AND DISCUSSION}

There are several simulation models that are used for projecting the agricultural sector in the EU; authors of this study attempted to identify the most significant models and classified them according to the classification system shown in Figure 1.

\section{General equilibrium models}

GEM-E3 is a recursive dynamic calculable general equilibrium model that covers the interplay between the energy system, economy and the environment. This model represents 28 European Member States (EU Science Hub, n.d.). The objective of GEM-E3 in supporting policy analysis is the consistent assessment of distributional effects (Paroussos, Fragkos and Capros, 2016). The GEM-E3 model is widely used as a tool of policy analysis and impact assessment (European Commission, 2013). The model uses GTAP and EUROSTAT databases (EU Science Hub, n.d.).

The main objective of MAGNET is to ensure a globally applied general equilibrium modelling framework. It has been used to simulate the impacts of agricultural, trade, land, and bioenergy policies on the global economy (MAGNET, 2015). The list structure of MAGNET has been designed to make it easy to find base data, scenarios created, policies accomplished as well as outcomes and tools to analyse output (Woltjer and Kuiper, 2014).

\section{Partial equilibrium models}

Aglink is a comprehensive partial equilibrium model for global agriculture, and is used to generate projects for many OECD-FAO countries. This model is an important tool for analysis of domestic and trade poli- cies (Aglink-Cosimo, 2015). Since its establishment, Aglink has played a significant role in the mediumterm outlook activity of the OECD. It has the ability to develop alternative scenarios and is used by the OECD Secretariat and collaborating countries to develop a forward-looking policy analysis (Adenauer, 2008). In 2004, it was decided to increase the number of developing regions and countries included in the Aglink project and develop an annual medium-term forecast in cooperation with the FAO, and the new element which was appended to the model called COSIMO (Adenauer, 2008). Currently, the Aglink model is used to predict the development of the EU agricultural sector.

The AGMEMOD model is an econometric and dynamic model with which it is possible to make projections and simulations assessing agricultural support instruments, programmes and policies at an EU level and at an individual Member States level ${ }^{4}$. The AGMEMOD model allows certain country models to reflect diversity in agro-climactic conditions, agricultural structures and agricultural output that exists between EU Member States. Using the bottom-up approach, the purpose is to better assess heterogeneity in the EU's agricultural sector (Chantreuil, Salputra and Erjavec, 2013). AGMEMOD includes all EU Member States and individual non-EU countries, such as Turkey, Russia and the Ukraine (AGMEMOD, 2012). Currently, the AGMEMOD model is used to predict the development of the EU agricultural sector.

CAPRI is a comparative static partial equilibrium model for the agricultural sector. The CAPRI system consists of specific databases, methodology, software implementation and researchers. The main purpose of the model is to evaluate the impact of common agricultural policy instruments in the EU, its Member States and also on a transnational level (Britz and Witzke, 2014).

CAPRI is designed to evaluate the impact of policies and markets from global to regional and farm levels (Frank et al., 2014). The database includes about 50 primary agricultural and processing products in the EU, as well as regional data, from farm level to global level coefficients (Britz and Witzke

${ }^{4}$ AGMEMOD website http://www.agmemod.eu/ [Accessed 16.01.2018]. 
et al., 2014). Currently, the CAPRI model is used to predict the development of the EU agricultural sector.

ESIM is a multi-country model of agricultural production, use of agricultural products, and some first-stage processing activities. With ESIM, only the agricultural sector is modelled, so macroeconomic variables such as revenue or exchange rates are exogenous. ESIM is a world model and it includes all countries, though in highly varying degrees of disaggregation. In the current version of ESIM covers 25 EU Members, Belgium and Luxembourg summarized as one region, Turkey and the US as well as the Western-Balkans (Grethe and Atavia et al., 2012). Currently, the ESIM model is used to predict the development of the EU agricultural sector.

GLOBIOM-EU is a global recursive dynamic partial bottom-up model of the forest and agricultural sectors (Frank et al., 2016). Partial means that the model does not contain the whole range of economic sectors of the country or region, but specializes in the production of agricultural and forestry products, as well as the production of bioenergy. GLOBIOM is used to analyse competition for land use between agriculture, forestry, and bioenergy (GLOBIOM model, 2012). The aim function calculates the balance of agriculture and forestry in the global market considering different activities such as land use and product processing activities (Frank et al., 2014).

\section{Agent-based model}

AgriPoliS is a model of regional agricultural structures. AgriPoliS is based on an understanding of the regional agricultural structure as a complex and developing system (Happe, Kellermann and Balmann, 2006). The aim of the model is to understand how farm structures change within a region in response to different policies, including the assessment of the influence of CAP on agricultural landscapes, biodiversity and ecosystem services (Brady, n.d.).

Each model has its own advantages, but it depends on the purpose of their use. These models allow policy makers to model different development scenarios and can be used as a tool for decision making (Table 1).

At present, CAPRI, Aglink-Cosimo, AGMEMOD and ESIM models are being used to predict the devel-

Table 1. Models comparison

\begin{tabular}{|c|c|c|c|}
\hline Model & Type of model & Model specific & Application \\
\hline GEM-E3 & $\begin{array}{l}\text { general equilibrium } \\
\text { model }\end{array}$ & $\begin{array}{l}\text { covers the interactions between the economy, the energy } \\
\text { system and the environment }\end{array}$ & EU \\
\hline MAGNET & $\begin{array}{l}\text { general equilibrium } \\
\text { model }\end{array}$ & $\begin{array}{l}\text { models the impacts of agricultural, trade, land, and } \\
\text { bioenergy policies on the global economy }\end{array}$ & EU \\
\hline Aglink-Cosimo & $\begin{array}{l}\text { partial equilibrium } \\
\text { model }\end{array}$ & important tool for analysis of domestic and trade policies & OECD countries \\
\hline CAPRI & $\begin{array}{l}\text { partial equilibrium } \\
\text { model }\end{array}$ & $\begin{array}{l}\text { is designed to evaluate the impact of policies and markets } \\
\text { from global to regional and farm levels }\end{array}$ & EU \\
\hline AGMEMOD & $\begin{array}{l}\text { partial equilibrium } \\
\text { model }\end{array}$ & $\begin{array}{l}\text { aims to make projections and simulations to assess } \\
\text { agricultural support instruments, programmes and policies }\end{array}$ & EU \\
\hline ESIM & $\begin{array}{l}\text { partial equilibrium } \\
\text { model }\end{array}$ & $\begin{array}{l}\text { use of agricultural products, and some } \\
\text { first-stage processing activities }\end{array}$ & $\begin{array}{l}25 \text { EU Members and } \\
\text { the rest of the world }\end{array}$ \\
\hline GLOBIUM-EU & $\begin{array}{l}\text { partial equilibrium } \\
\text { model }\end{array}$ & $\begin{array}{l}\text { used to analyze competition for land use between } \\
\text { agriculture, forestry, and bioenergy }\end{array}$ & $\begin{array}{l}\text { EU and } 25 \text { regions } \\
\text { outside the EU }\end{array}$ \\
\hline AgriPoliS & agent-based model & $\begin{array}{l}\text { is based on an understanding of the regional agricultural } \\
\text { structure as a complex and developing system }\end{array}$ & EU \\
\hline
\end{tabular}

Source: authors' construction based on Zeverte-Rivza, Nipers and Pilvere (2017). 
opment of the agricultural sector in the EU (EU Agricultural Outlook, 2015). General equilibrium models (GEM-E3 and MAGNET) are comprehensive, their prevalence is globally applicable and can be adapted to analyse specific problems. Aglink-Cosimo is applied in OECD countries and allows to make medium and long-term annual agricultural forecasts by the OECD. This model is one of the most important OECD instruments for policy forecasting. The main task of the CAPRI model is to assess the impact of agricultural policy in the $\mathrm{EU}$ and the market, from a global to regional level, not only at an EU level but also transnationally. AGMEMOD is another model which is used to evaluate EU agricultural policy and anticipate the development of the EU agricultural sector. The ESIM model is only used to model the agricultural sector in $25 \mathrm{EU}$ member states and ROW. The main objective of GLOBIOM-EU is to forecast the demand for agricultural and forestry products in 53 regions of the world (28 EU Members and 25 regions outside the EU). AgriPoliS is a model of regional agricultural structure that reflects the changing structure of agricultural sector in regions as a result of agricultural policy instruments.

\section{CONCLUSIONS}

Simulation modelling is often used in the agricultural sector by policy makers. The most popular models used for simulations are: system dynamic, agentbased, hybrid and discrete event models.

Diverse models are used in the EU for simulation of the agricultural sector. There are eight key models of different complexity used to predict the development of the agricultural sector in the EU and OECD countries. These models are used to develop an outlook for the agricultural sector and adjust policy measures of the EU and its member states to promote the most beneficial economical development of the agricultural sector.

\section{REFERENCES}

1. Adenauer, M. (2008). CAPRI versus AGLINK-COSIMO Two Partial Equilibrium Models - Two Baseline Approaches. In: 12th Congress of the European
Association of Agricultural Economists - EAAE 2008, Ghent.

2. Aglink-Cosimo (2015). Model Documentation Retrieved from: http://www.agri-outlook.org/about/ [Accessed 22.01.2018].

3. AGMEMOD (2012). Future Plans of AGMEMOD. Consortium meeting. Brussels.

4. Berger, T. (2001). Agricultural Economics. Journal of the International Association of Agricultural, 25, pp. 245-260.

5. Brady, M. (n.d.). AgriPoliS - an agent-based model of regional agricultural structures. Retrieved from: http://www.agrifood.se/engmodel.aspx?fKeyID $=91$ [Accessed 16.01.2018].

6. Britz, W., Witzke, H.P. (2012). CAPRI Model Documentation 2012. In: CAPRI Model Documentation 2012. Bonn.

7. Bryant, W.D.A. (2010). General Equilibrium: Theory and Evidence. World Scientific Publishing Company, London.

8. Chantreuil, F., Salputra, G., Erjavec, E. (2013). Market Analysis of Direct Payment Options for New EU Member States Using the AGMEMOD Partial Equilibrium Modelling Tool. Outlook on AGRICULTURE, 42 (10), pp. 33-40. DOI: 10.5367/oa.2013.0111

9. EU Science Hub (n.d.). GEM-E3. Retrieved: https://ec.europa.eu/jrc/en/gem-e3/model [Accessed 24.01.2018].

10. European Commission (2013). GEM-E3 Model Documentation. Retrieved from: http://publications. jrc.ec.europa.eu/repository/bitstream/JRC83177/ jrc83177\%20(3).pdf [Accessed 24.01.2018].

11. Frank, S., Forsell, N., Gusti, M., Havlík, P. (2016). Methodology for estimation and modelling of EU LULUCF greenhouse gas emissions and removals until 2050 in GLOBIUM and G4M. Report: European Commission.

12. Frank, S., Witzke, P., Zimmermann, A., Havlik, P., Ciaian, P. (2014). Climate Change Impacts on European Agriculture: A Multi Model Perspective. In: EAAE 2014 Congress Proceedings: Agri-Food and Rural Innovations for Healthier Societies, Ljubljana 26-29.08.2014.

13. GLOBIOM model (2012). European Commission, Climate Analysis Models. Retrieved from: https:// ec.europa.eu/clima/sites/clima/files/strategies/analysis/ models/docs/globiom_en.pdf [Accessed 17.01.2018].

14. Grethe, H. (ed.), Atavia, M., Banse, M., Boysen, O., Deppermann, A., Nolte, S. (2012). European Simulation Model (ESIM): Documentation (Model Code, Parameterization, Database). 
15. Happe, K., Balmann, A., Kellermann, K., (2004). The Agricultural Policy Simulator (AGRIPOLIS) - an Agent-based Model to Study Structural Change in Agriculture (Version 1.0). Discussion Papers 2004 Institute of Agricultural Development in Central and Eastern Europe (IAMO), Germany.

16. Happe, K., Kellermann, K., Balmann, A. (2006). Agent-based Analysis of Agricultural Policies: an Illustration of the Agricultural Policy Simulator AgriPoliS, its Adaptation and Behavior. Ecology and Society, 11, p. 27.

17. Kotevska, A., Dimitrievski, D., Erjavec, E. (2013). Partial Equilibrium Model as a Tool for Policy Analysis in Agriculture: an Empirical Evidence of Makedonia. Agriculture and Rural Development - Challenges and Integration Processes, Belgrade-Zemun, pp. 52-65.

18. Lofgren, H., Harris, R.L., Robinson S. (2002). A Standard General Equilibrium Model (CGE) in GAMS. International Food Policy Research Institute.

19. Martin, L.A. (1997). The First Step. System Dynamics in Education Project. Massachusetts Institute of Technology.
20. Modular Applied General Equilibrium Tool (2015). Retrieved from: http://ledsgp.org/resource/modularapplied-general-equilibrium-tool/?loclang=en_gb [Accessed 17.01.2018].

21. Paroussos, L., Fragkos, P., Capros, P. (2016). A model-based analysis of the European Intended Nationally Determined Contribution. Institute for Sustainable Development and International Relations.

22. Richiardi, M.G. (2012). Agent-based Computational Economics: A Short Introduction. Agent-Based Computational Economics, 27, pp. 137-149.

23. Sharma, M. (2015). Discrete-Event Simulation. International Journal of Scientific \& Technology Research, 4, pp. 136-140.

24. Woltjer, G.B., Kuiper, M.H. (2014). The MAGNET Model: Module description. Retrieved from: http:// ledsgp.org/wp-content/uploads/2015/10/MagnetModuleDescription.pdf [Accessed 25.01.2018].

25. Zeverte-Rivza, S., Nipers, A., Pilvere, I. (2017). Agricultural production and market modelling approaches. Economic Science for Rural Development, 45, pp. 267-274 . 